\title{
PERKEMBANGAN ISLAM INDONESIA
}

\author{
M. Yakub \\ IAIN Sumatera Utara \\ Yakub.m70@yahoo.co.id
}

\begin{abstract}
Abstrak
Selama ini masih ada perdebatan di antara para ahli tentang historiografi Islam di Indonsia. Ada asumsi bahwa nilai historiografi yang standar hanya dimiliki oleh sejarawan akademis, sementara sejarawan informal tidak memiliki tempat dalam khazanah historiografi yang ada. Padahal dari aspek produktifitas para sejarawan informal itu cenderung lebih produktif dalam melahirkan karya-karya sejarah sepanjang zaman. Artikel ini difokuskan pada kajian tentang sejarah dan perkembangan Islam di Indonesia. Pada titik kajian ini terdapat tiga corak pendekatan, yaitu pertama, pendekatan sejarah Islam Indonesia sebagai bagian dari sejarah umat Islam; kedua, pendekatan sejarah Islam Indonesia sebagai bagian dari sejarah nasional Indonesia; dan ketiga, pendekatan Global yang secara implisit mengemukakan bahwa perkembangan historis di suatu wilayah tertentu tidaklah terjadi dan berlangsung dalam situasi vakum dan isolatif. Akan tetapi, ia terkait dengan peristiwa-peristiwa pada kawasan lain. Sehingga Islam Indonesia harus dilihat dan ditempatkan dalam kerangka sejarah dunia pada umumnya; bukan sejarah yang berdiri sendiri.
\end{abstract}

\begin{abstract}
THE HISTORICITY OF THE DEVELOPMENT OF ISLAM IN INDONESIA: So far, there is still ongoing debates among the experts of Islamic historiography on the assumption that the standard value of historiography can only be achieved by academic historians, while informal historian has no place in the treasury of the existing historiography. In fact, from the aspect of productivity, informal historians tend to be more productive in the birth of the historical works. This article focuses on the study of the historicity of
\end{abstract}


Islam in Indonesia. In this study, there are three approaches that can be applied: first, the approach of the history of Islam in Indonesia as part of the history of the Muslims; The second approach is the history of Islam in Indonesia as part of Indonesian national history; and the third, the global approach which suggests that the historical development in a particular area does not occur and take place in a vacuum situation and isolated. On the contrary, it is always associated with events in other regions. The Indonesian Islam, therefore, should be placed within the framework of the history of the world, not as a stand-alone history.

Kata Kunci: Informal historians, Historiography, Indonesian Islamic.

\section{A. Pendahuluan}

Historiografi (Islam) Indonesia, setidaknya dalam beberapa dasawarsa terakhir, ditandai dengan adanya beberapa perkembangan penting baik secara kuantitatif maupun kualitatif. Menurut Azyumardi Azra, Secara kuantitatif munculnya karya-karya sejarah, baik yang ditulis sejarawan Indonesia sendiri maupun sejarawan asing, karya-karya itu dapat dikategorikan sejarah lokal maupun nusantara, dan global. Karya-karya sejarah ini telah memberikan sumbangan yang signifikan dalam upaya pemahaman yang lebih akurat terhadap sejarah Indonesia secara keseluruhan. ${ }^{1}$ Sementara secara kualitatif, menurut Kuntowijoyo, terlihat dari penggunaan metodologi yang semakin kompleks, yang melibatkan cukup banyak ilmu bantu, khususnya ilmu-ilmu humaniora lainnya. ${ }^{2}$

Penggunaan ilmu-ilmu bantu dalam penulisan sejarah Indonesia secara umum dan sejarah Islam Indonesia khususnya, menurut Azra, tidak dapat dipungkiri telah memperkuat dan mengembangkan corak baru dari apa yang disebut kalangan sejarawan Indonesia sebagai "sejarah baru" (new history), sebagai kontra dari "sejarah lama" (old history), yang umumnya bersifat naratif dan deskriptif, atau yang biasa disebut "sejarah ensi-

${ }^{1}$ Azyumardi Azra, Historiografi Islam Kontemporer: Wacana Aktualitas dan Aktor Sejarah. (Jakarta: PT. Gramedia Pustaka Utama, 2002), h. 3.

${ }^{2} I l m u-i l m u$ humaniora semacam antropologi dan ilmu-ulmu sosial seperti sosiologi, ilmu politik, ilmu ekonomi, dan lain-lain. Untuk melihat perkembangan sejarah sosial lihat Kuntowijoyo, Metodologi Sejarah, (Yogyakarta: Tiara Wacana Yogya, 2003), h. 39-58. 
klopedis". ${ }^{3}$ Tetapi "sejarah baru" itu sendiri, sebagaimana baru saja diisyaratkan, juga mengalami perkembangan yang cukup signifikan. Pada awal kemunculannya, terutama sejak 1960-an, "sejarah baru" pada umumnya dipahami sebagai alternatif, jika tidak sebagai tandingan "sejarah lama" yang cenderung merupakan "sejarah politik". ${ }^{4}$ Dalam melacak historiografi Islam awal di Indonesia, Rossenthal melihat bahwa bentuk dasar historiografi Islam di Indonesia adalah karya sastra klasikyang isinya banyak menyebutkan istilah-istilah kepada narasi tertentu seperti haba, hikayat, kisah, tambo dan lainnya yang berasal dari bahasa Arab. ${ }^{5}$ Argumen ini didukung HAMKA dalam melakukan penulisan Sejarah Umat Islam IV banyak bahannya yang diambil dari historiografi lokal meski bercampur mitos dan legenda, seperti Hikayat Raja-raja Pasai, Sejarah Melayu, dan lain-lain yang menjelaskan interaksi langsung antara Nusantara dengan Arabia. ${ }^{6}$

Adanya karangan klasik seperti haba, hikayat, kisah, tambo inilah yang oleh Rossenthal disebut dapat dijadikan bahan penting dalam studi karya historiografi Islam, sehingga akan terbentuk suatu horizon baru di dalam penulisan sejarah Islam yang lebih banyak berpijak pada bumi sendiri dalam pengembangan keahlian dan pengetahuan sejarah Islam yang dilakukan oleh penulis-penulis Islam sendiri. ${ }^{7}$

Menurut Mukti Ali paling tidak terdapat dua corak pendekatan dalam penulisan sejarah Islam di Indonesia. Pertama, Pendekatan sejarah Islam Indonesia sebagai bagian dari sejarah umat Islam, kedua, pendekatan sejarah Islam Indonesia sebagai bagian dari sejarah nasional Indonesia. ${ }^{8}$ Pendekatan sejarah Islam Indonesia sebagai bagian dari sejarah umat Islam diperkenalkan oleh HAMKA dalam bukunya Sejarah Umat Islam IV. ${ }^{9}$

${ }^{3}$ Azyumardi Azra, "Historiografi Islam Indonesia: Antara Sejarah Sosial, Sejarah Total, dan Sejarah Pinggir”, Menjadi Indonesia: 13 Abad Eksistensi Islam di Bumi Nusantara, (Jakarta: Mizan, 2006), h. 4.

${ }^{4}$ Azra, Historiografi Islam Kontemporer, h. 4.

${ }^{5}$ A. Muin Umar, Historiografi Islam, (Jakarta: Rajawali Press, 1988), h. 188.

${ }^{6} \mathrm{HAMKA}$, Sejarah Umat Islam IV, (Jakarta: Bulan Bintang, 1981). h. 29

${ }^{7}$ Franz Rosenthal, A History of Muslim ( Leiden:E.J Brill, 1968), h. 8.

${ }^{8}$ A. Muin Umar, Historiografi ..., h.188.

${ }^{9}$ HAMKA, Sejarah..., h. 27 


\section{B. Perdebatan Tentang Awal Masuknya Islam ke Indonesia}

Islam masuk ke Indonesia menurut Hamka pada awal abad ke-7. Artinya, Islam masuk ke Indonesia pada awal abad hijriyah, bahkan pada masa Khulafaur Rasyidin memerintah. Islam sudah mulai ekspedisinya ke Nusantara ketika sahabat Abu Bakar as Siddiq, Umar bin Khațab, Ușman bin Affan dan Ali bin Abi Thalib memegang kendali sebagai Amirul Mukminin.

Teori HAMKA iniyang kemudian dikenal dengan teori Arabia. ${ }^{10}$ Teori ini juga didukung oleh Badri Yatim dalam bukunya Sejarah Peradaban Islam. Namun Yatim lebih melihat pada sisi politiknya, dengan artian bahwa perkembangan masyarakat Islam di Indonesia baru terdapat ketika "komunitas Islam" berubah menjadi pusat kekuasaan. ${ }^{11}$

Sementara Taufik Abdullah tidak menyetujui tentang teori yang mengatakan bahwa datangnya Islam pertama kali ke Indonesia pada abad ke- $7 \mathrm{M}$ dengan alasan belum ada bukti bahwa pribumi Indonesia di tempat-tempat yang disinggahi oleh para pedagang Muslim itu beragama Islam. Adanya koloni itu, diduga sejauh yang paling bisa dipertanggungjawabkan, ialah para pedagang Arab tersebut, hanya berdiam untuk menunggu musim yang baik bagi pelayaran. ${ }^{12}$

Namun berdasarkan bukti catatan-catatan resmi dan Jurnal Cina pada periode ini Dinasti Tang ${ }^{13} 618$ M secara ekplisit menegaskan bahwa Islam sudah masuk wilayah Timur jauh, yakni Cina dan sekitarnya ${ }^{14}$ pada abad pertama Hijriah melalui lintas laut dari bagian Barat Islam. Cina yang dimaksudkan pada abad pertama Hijriah tiada lain adalah gugusan pulau-pulau di Timur Jauh termasuk Kepulauan Indonesia. ${ }^{15}$

${ }^{10}$ HAMKA, Sejarah..., h. 36-42. Lihat juga Alwi Sihab, Antara Tasawuf Suni \& Tasawuf Falsafi: Akar Tasawuf di Indonesia, (Jakarta: Pustaka IIMaN, 2009), h. 6-12.

${ }^{11 B a d r i}$ Yatim, Sejarah Peradaban Islam, (Jakarta: Raja Grafindo Persada, 2006), h. 191-193.

${ }^{12}$ Taufik Abdullah (Ed), Sejarah Umat Islam Indonesia, (Jakarta: Majelis Ulama Indonesia, 1991), h. 34. 1977), h. 73.

${ }^{13}$ Sartono Kartodirjo, Sejarah Nasional Indonesia, vol. II, (Jakarta: Depdikbud,

${ }^{14}$ G. R. Tibbets, "Early Muslim Trade in South Asia” Vol. 30 (t.t.: MBRAS, 1957), h. 39.

${ }^{15}$ Yaqut al-Hamari, Mu’Jam al-Buldān, vol. III, (Beirut: Dār Shadir, 1971), h. 440. 
Jurnal Cina juga mengisyaratkan adanya pemukiman Arab di Cina yang penduduknya diizinkan oleh Kaisar untuk sepenuhnya menikmati kebebasan beragama. ${ }^{16}$ Pada masa itu orang-orang Islam memilih pemimpin mereka sendiri yang dinamakan imam, ${ }^{17}$ dan sejak masa itu perdagangan Indonesia mulai lancar dan maju.

Selain itu, laporan Cina yang menegaskan keputusan bangsa Arab mengirim utusan kepada Kerajaan Ho Long. Kerajaan Arab mengirim utusan ke Kerajaan Ho Long sekitar tahun 640 M, 666 M, dan 674 M. ${ }^{18}$ Sementara Kerajaan Ho Long sendiri menurut Alwi Sihab $^{19}$ terletak di Jawa Timur yang bernama Kerajaan Kalingga yang terkenal dengan kemajuan dan kesejahteraan rakyat serta keadilan pemerintahannya. Sementara yang mengutus oleh orang-orang Cina dikenal dengan sebutan "Tașhịḥ" sebagai nama yang mereka kenal untuk kerajaan Arab. ${ }^{20}$ Jadi, pengenalan dini kaum Muslimin (Arab) terhadap Kepulauan Indonesia setaraf dengan data yang mereka ketahui mengenai Cina bahkan lebih luas.

Jika demikian halnya, alasan apakah yang menjadi penghalang untuk menetapkan bahwa Islam masuk ke Indonesia pada abad pertama Hijriyah. Yaitu, pada masa pedagang-pedagang Muslim memasuki Cina karena kedatangan orang-orang Arab membawa Islam ke Cina melalui jalur laut lama.

Selain pendekatan di atas, dalam pendekatan historiografinya, HAMKA lebih banyak menekankan kepada periode daripada daerah. Penekannya lebih banyak kepada peranan pahlawan dan Sultan dalam bangun dan tenggelamnya kerajaan Islam di kepulauan Nusantara, sehingga ia dikenal sebagai penulis sejarah heroworship. ${ }^{21}$

Pendekatan penulisan sejarah Islam Indonesia yang menekankan pada periode juga dilakukan oleh Yahya Harun. ${ }^{22}$ Ia

${ }^{16}$ Dr. J.C. van Leur, Indonesian Trade and Society, (Den Haag: W. Van Hoeve Ltd, 1995), h. 440.

${ }^{17}$ Alnold, T. W. The Preaching of Islam, (London: tp, 1935), h. 331-332.

${ }^{18}$ Grenvelt, W.P., Historical Notes on Indonesia and Malaya Compiled From Chinese Sources, (1960), h. 201.

${ }^{19}$ Sihab, Antara Tasawuf..., h. 11.

${ }^{20}$ Sartono Kartodirjo, Sejarah Nasional Indonesia, h. 73.

${ }^{21}$ Umar, Historiografi..., h. 185.

${ }^{22}$ Yahya Harun, Islam Nusantara Abad XVI \& XVII, (Yogyakarta: Kurnia Kalam Sejahtera 1995). 
lebih tertarik terhadap pertumbuhan, perkembangan, dan runtuhnya suatu kerajaan Islam di bumi Nusantara ini, begitu juga ia lebih menekankan pada peranan pahlawan dan sultan dan mengecilkan peranan masyarakat dalam mengembangkan Islam di bumi nusantara ini.

Dari uraian tentang beberapa tulisan sejarah Islam di Indonesia diatas sudah memberi gambaran sekilas tentang adanya karya-karya sejarah Islam yang ditulis oleh penulis-penulis dahulu. Namun tulisan sejarah Islam awal di Indonesia lebih mengarah pada teori dan metode sejarah konvensional yang lebih menonjolkan proses dan tokoh politik serta mengungkapkannya sebagai tulisan deskriptif-naratif, bagaimana peristiwa-peristiwa itu terjadi. Juga, memasukkan peristiwa-peristiwa berdasarkan pembabaran besar dalam suatu proses yang linier. Sejarah sebagai suatu narasi besar diperlihatkan melalui peristiwa dan tokoh besar dengan mendokumentasikan asal-usul kejadian, menganalisis genealogi, lalu membangun dan mempertahankan singularitas peristiwa, memilih peristiwa yang dianggap spektakuler (seperti perang), serta mengabaikan peristiwa yang bersifat lokal ${ }^{23}$

Sementara pendekatan sejarah Islam Indonesia sebagai bagian dari sejarah nasional Indonesia diperkenalkan oleh Uka Tjandrasasmita, seorang arkeolog yang keahliannya khusus mengenai peninggalan-peninggalan Islam di Indoenesia. Ia telah mempergunakan sumber sekunder baik berupa buku, artikel dan lain-lainnya, maupun naskah-naskah, hikayat-hikayat daerah dan berita-berita asing yang pernah diterbitkan. Dalam penulisan sejarah Islam Indonesia ia lebih menekankan pada sejarah sebagai proses dalam masyarakat yang terjadi karena pergeseran elemen-elemen yang terdapat dalam masyarakat itu dan kurang memberikan peranan tokoh. ${ }^{24}$

Selain dari Uka Tjandrasasmita, Taufik Abdullah juga menggunakan pendekatan yang sama dalam penulisan sejarah Islam

${ }^{23}$ Togi Simanjuntak, Peneliti Sejarah Sosial dan Sejarah Kekerasan pada Institut Riset Sosial dan Ekonomi (Inrise) Lihat http://www.duniaesai.com/ sejarah/sejarah2.html (diakses pada 01 April 2009).

${ }^{24}$ Uka Tjandrasasmita, Sejarah Nasional Indonesia III, (Jakarta: Balai Pustaka, 1977). 
Indonesia. Ia menulis sejarah Islam dalam lingkup sejarah nasional. ${ }^{25}$ Dalam bukunya Sejarah Umat Islam Indonesia Taufik Abdullah membahas tentang perjuangan umat Islam di Indonesia, yang semula berada dalam konteks politik yang bersifat fragmentaris, untuk membentuk situasi yang integratif - bangsa dan negara Indonesia. Sejarah Islam Indonesia bukan saja merintis proses ke arah integratif nasional, tetapi juga menemukan afinitas dengan nasionalisme Indonesia. ${ }^{26}$

Munculnya pendekatan sejarah Islam Indonesia sebagai bagian dari sejarah nasional Indonesia yang diidentikkan oleh Sartono Kartodirdjo sebagai kumpulan sejarah-sejarah lokal, ${ }^{27}$ secara implisit menggambarkan penulisan baru sejarah Islam Indonesia. Pendekatan semacam itu lebih menekankan pada sejarah sebagai proses dalam masyarakat yang terjadi karena pergeseran elemenelemen yang terdapat dalam masyarakat itu. ${ }^{28}$

Kalau kita perhatikan, perkembangan historiografi Islam di Indonesia mengalami perkembangan bersamaan dengan perkembangan historiografi Indonesia itu sendiri. Historiografi Indonesia dimulai dengan munculnya corak historiografi tradisional yang mempunyai unsur-unsur yang tidak bisa lepas dari karya mitologi dimana pihak kerajaan mempunyai peranan penting seperti Empu Prapanca yang menulis kitab Negara Kertagama. ${ }^{29}$

Kemudian pada zaman kolonial penulisan sejarah didominasi oleh orang-orang Eropa yang datang ke Indonesia. Penulisan sejarah pada masa ini bersifat Eropa-sentris. ${ }^{30}$ Setelah Indonesia merdeka mulailah penulisan sejarah yang didominasi oleh para penulis Indonesia yang memperkenalkan historiografi dengan

${ }^{25}$ Taufik Abdullah (Ed), Sejarah Umat Islam Indonesia, (Jakarta: Majelis Ulama Indonesia, 1991).

${ }^{26}$ TIbid, Sejarah ..., h. 17.

${ }^{27}$ Sartono Kartodirdjo, dkk, Lembar Sejarah, Beberapa Fasal Dari Historiografi Indonesia, (Yogyakarta: Yayasan Kanisius, 1968), h.17.

${ }^{28}$ Tjandrasasmita, Sejarah ....., h. 123

${ }^{29}$ Pada zaman ini yang menjadi penulis sejarah adalah para pujanggapujangga yang bertujuan untuk memuji dan mengkultuskan Raja sebagai pusat kosmik, dan lebih kepada konsep Istana-sentris. Lihat Sartono Kartodirdjo, Pemikiran dan ..., h. 25.

${ }^{30}$ Azra, Historiografi Islam Kontemporer..., h. 8. 
pendekatan Indonesia-sentris. Fokus penulisan sejarah pada masa ini mengangkat tentang tokoh-tokoh pahlawan nasional yang telah berjasa dalam memperjuangkan kemerdekaan dan bahkan banyak biografi-biografi tokoh pahlawan nasional yang diterbitkan. ${ }^{31}$

\section{Perspektif Baru Historiografi Islam Indonesia}

Perkembangan baru dalam historiografi Islam Indonesia, dalam pandangan Azra, ditandai dengan munculnya beberapa karya besar sejarah yang melihat sejarah dalam perspektif global. Dalam perspektifsejarah global ini, sejarah Islam Indonesia harus dilihat dan ditempatkan dalam kerangka sejarah dunia pada umumnya. ${ }^{32}$ Salah satu karya sejarah yang menempatkan sejarah pada kerangka global adalah karya Denys Lombard, Nusa Jawa: Silang Budaya, 3 Jilid (aslinya, Le Carrefour Javanais: Essai d'histoire globale, pertama diterbitkan pada 1990). Menurut Azra, karya Denys Lombard dengan judul Nusa Jawa ini telah turut mewakili dan memperkuat momentum bagi kemunculan corak historiografi yang relatif baru bagi kajian-kajian sejarah Indonesia. ${ }^{33}$

Karya lain yang meletakkan kerangka sejarah global adalah mahakarya Anthony Reid, Southeast Asia in the Age of Commerce 14501680. Karya ini diterbitkan dalam dua jilid; jilid pertama, Southeast Asia in the Age of Commerce, Volume One: The Lands below the Winds (1988) dan jilid kedua, Southeast Asia in the Age of Commerce 1450-1680, Volume Two:Expansion and Crisis (1993) ${ }^{34}$

Menurut Azra, kedua karya ini melihat "Nusa Jawa" sesuai istilah Lombard, atau "Negeri Bawah Angin" menurut istilah Reid, dalam perspektif global, persisnya dalam kaitannya dengan perkembangan lingkungan, bahkan dunia di sekitar kedua wilayah tersebut. ${ }^{35}$ Perspektif ini secara implisit mengemukakan suatu filosofis sejarah yang menegaskan bahwa perkembangan historis di suatu wilayah tertentu tidaklah terjadi dan berlangsung dalam situasi vakum dan isolatif.

\footnotetext{
${ }^{31}$ Ibid., h. 8.

${ }^{32}$ Ibid., h. 4. dan 14.

${ }^{33}$ Ibid., h.13.

${ }^{34}$ Ibid., h. 7.

${ }^{35}$ Ibid., h. 13.
} 
Akan tetapi, ia terkait dengan peristiwa-peristiwa pada kawasan lain. Dengan demikian, dalam perspektif ini, sejarah Indonesia harus dilihat dan ditempatkan dalam kerangka sejarah dunia pada umumnya; bukan sejarah yang berdiri sendiri. Hasilnya, pendekatan ini secara implisit berisi pengakuan, bahwa sejarah Indonesia merupakan bagian yang sah dari sejarah dunia secara keseluruhan. $^{36}$

Pendekatan semacam ini, menurut Azra, secara tidak langsung merupakan revisi atas dua pendekatan yang selama ini populer dalam historiografi Indonesia. Pertama, pendekatan yang bersifat eurosentris-atau lebih tegas lagi dalam kontek Indonesia Nederlando-sentris (berpusat pada Belanda). ${ }^{37}$

Dalam pendekatan ini, sejarah Indonesia dipandang sebagai bagian dari sejarah kolonialisme Eropa, persisnya ekspansi dan konsolidasi Belanda. Sebagai konsekuensinya, sejarah masyarakatmasyarakat pribumi Indonesia diposisikan tidak pada tempat yang marjinal, tetapi bahkan juga dalam perspektif yang peyoratif. ${ }^{38}$

Kedua, pendekatan yang bersifat 'indo-sentris", ${ }^{39}$ persisnya yang bertujuan menjadikan Indonesia sebagai sentral atau pusat wacana sejarah. Pendekatan ini sebenarnya berusaha menghindari "ektrimitas" sejarah Euro-sentris, namun pada gilirannya terjerembab ke kutub ekstrem lainnya. Meski pendekatan Indo-sentris terlihat seolah-olah bertolak belakang dengan pendekatan Eurosentris, namun pandangan dunia yang mendasari keduanya pada dasarnya sama, yakni motif-motif atau kepentingan-kepentingan ideologi tertentu. ${ }^{40}$

Di samping itu, karya Reid atau Lombard juga menggambarkan tentang "sejarah sosial". Walaupun dalam karyanya Lombard memakai istilah "Nusa Jawa" tetapi menurut Azra, pembahasan yang diberikan Lombard lebih dari sekedar tentang "Pulau Jawa" sebagaimana kita kenal tetapi pembahasannya dapat dikatakan mencakup seluruh "Nusantara", dengan Jawa sebagai

\footnotetext{
${ }^{36}$ Ibid., h. 7.

${ }^{37}$ Kartodirdjo, Pemikiran.........., h. 19-22.

${ }^{38}$ Azra, "Historiografi I..., h. 14.

${ }^{39}$ Kartodirdjo, Pemikiran dan ..., h. 22-23.

${ }^{40}$ Azra, "Historiografi..., h. 15.
} 
fokus utamanya ${ }^{41}$ Begitu juga ketika dilihat dari sub judul karya Lombard berbunyi Essai d'histoire globale yang menurut Azra, secara harfiah seharusnya diterjemahkan sebagai "Esai Sejarah Total" 42 secara emplisit menjelaskan corak penulisan sejarah yang dianut oleh Lambard yakni sejarah global atau, lebih populer lagi, "sejarah Total" (total history), yang sering juga disbut disebut sebagai "New History". ${ }^{3}$

Dengan sub judul ini mengisyaratkan bahwa Lombard ingin menulis sejarah Jawa secara global atau tepatnya, secara total. Dan ini dengan segera menjelaskan akar-akar historiografi yang mendasari pandangan dunia seorang Lombard. Dengan pendekatan sejarah global (total), Lombard dengan leluasa membahas berbagai aspek kehidupan masyarakat dalam perkembangan historisnya, sejak dari geografi, pelapisan sosial, demografi, estetika, ekonomi dan perdagangan, birokrasi, peranan wanita, dan seterusnya.

Dari paparan kedua karya tersebut telah memberi gambaran tentang perkembangan historiografi Indonesia. Harus diakui bahwa kedua karya tersebut di atas telah mempengaruhi corak historiografi Indonesia sehingga historiografi Indonesia semakin cenderung bersifat global dan total.

Perkembangan historiografi Indonesia ini diakui oleh Azra juga berdampak pada perkembangan historiografi Islam Indonesia. Dalam kurun waktu terakhir ini, sejarah Islam di Indonesia tidak lagi dilihat dari perspektif lokal, sebagaimana selama ini cenderung dilakukan para sejarawan, tetapi dalam perspektif global dan total, yang melihat sejarah Islam di Indonesia dalam kaitan dengan perkembangan historis Islam di kawasan-kawasan lain. ${ }^{44}$

Salah satu karya penting tentang sejarah Islam Indonesia yang menempatkan sejarah pada kerangka total atau global adalah

${ }^{41}$ Ibid., 11.

${ }^{42}$ Azra kurang sepakat dengan terjemahan bahasa Indonesia subjudul Essai d'histoire globale dengan "Kajian Sejarah Terpadu" . Menurut Azra Sub judul tersebut seharusnya diterjemahkan secara harfiah "Esai Sejarah Total" karena hal itu akan menggambarkan corak penulisan sejarah yang dianut oleh Lombard. Ibid., h. 11.

${ }^{43}$ Arthur Marwick, The Nature of History, Secon Edition, (London: Macmillan Education, 1985), h. 64.

${ }^{44}$ Azra, Historiografi......., h. 9. 
karya Azyumardi Azra Jaringan Ulama Timur Tengah dan Kepulauan Nusantara Abad XVII dan XVIII. ${ }^{45}$ Dalam karyanya ini, Azra melakukan penelitian terhadap ulama Nusantara, khususnya pada pada abad 17 dan 18 dalam kaitan dengan wacana intelektual keagamaan (religio-intellectual discourse) ulama Indonesia di Mekkah dan Madinah (Haramayn) dan sekaligus tentang hubungan dinamika Islam di Nusantara dengan perkembangan Islam di kawasan dunia Muslim lainnya.

Penelitian Azra tentang wacana intelektual keagamaan (religio-intellectual discourse) ulama Indonesia di Mekkah dan Madinah (Haramain) mencoba melacak sejarah sosial-intelektual ulama Nusantara dalam kaitannya dengan Dunia Islam yang lebih luas. Menurut Azra wacana intelektual keagamaan ini berpusat pada semacam jaringan ulama (networks of the ulama) yang berpusat di Mekkah dan Madinah (Haramayn). ${ }^{46}$

Kajian sejarah sosio-intelektual ulama Nusantara yang telah dilakukan Azra ini merupakan hal yang baru karena pada umumnya pengkajian tentang ulama-ulama Indonesia berbentuk pengkajian biografis, yang terlalu memusatkan pada ulama bersangkutan, sehingga cenderung terlepas dalam konteks sosio-intelektual yang mengitari mereka. Sementara itu, terdapat pula beberapa studi yang lebih memusatkan perhatian pada peran keagamaan dan politikyang mereka mainkan dalam kurun waktu tertentu sejarah Nusantara. ${ }^{47}$

Karya penting lainnya dari Azra yang perlu disebut dalam tarikan nafas yang sama adalah Islam Nusantara: Jaringan Global dan Lokal. ${ }^{48}$ Buku ini merupakan historical account tentang Islam di Nusantara dengan menggunakan pendekatan multidisipliner-ilmu sejarah yang dipadu dengan ilmu-ilmu lain, seperti antropologi, sosiologi, ilmu politik, perbandingan agama dan lain-lain. Karya Azra ini juga menegaskan bahwa perkembangan historis di suatu wilayah tertentu tidaklah terjadi dan berlangsung dalam situasi

${ }^{45}$ Azyumardi Azra, Jaringan Ulama Timur Tengah dan Kepulauan Nusantara Abad XVII dan XVIII, (Bandung: Mizan,1994).

${ }^{46}$ Azra, Historiografi......, h. 120.

${ }^{47}$ Azra, Jaringan......., h. 15.

${ }^{48}$ Azyumardi Azra, Islam Nusantara: Jaringan Global dan Lokal, (Bandung: Mizan, 2002). 
vakum dan isolatif. Tetapi ia terkait dengan peristiwa-peristiwa pada kawasan lain. Oleh karena itu, Azra melihat bahwa dinamika Islam Nusantara tidak pernah lepas dari dinamika dan perkembangan di kawasan-kawasan lain, wilayah yang kini disebut sebagai Timur Tengah. Kerangka, koneksi, dan dinamika global itu dapat dipastikan membentuk-atau setidak-tidaknya mempengaruhi-dinamika dan tradisi lokal di Nusantara. ${ }^{49}$

Kedua karya Azra ini secara implisit telah menjelaskan tentang corak penulisan sejarah yang dianutnya yakni sejarah global atau, lebih populer lagi, "Sejarah Total" (total history). Sejarah Islam di Indonesia, dalam pandangan Azra, harus dilihat dalam perspektif global dan total, yakni melihat sejarah Islam di Indonesia dalam kaitan dengan perkembangan historis Islam di kawasa-kawasan lain. Sehingga dengan studinya ini Azra berargumen bahwa perjalanan historis Islam di Indonesia sepanjang sejarah tak dapat dilepaskan dari perkembangan Islam di Arabia dan kawasan-kawasan Muslim lainnya. ${ }^{50}$

Karya sejarah lainnya yang sama dengan corak penulisan sejarah Azra adalah kajian yang dilakukan oleh Abaza tentang mahasiswa Indonesia di Kairo. Kajian Abaza dapat disebut sebagai "sejarah kontemporer" mahasiswa Indonesia yang menuntut ilmu di Kairo dan peranan mereka setelah kembali ke Indonesia. Kajian Abaza ini menekankan tentang proses cultural exchange, atau yang disebut Azra sebagai transmission of Islamic Learning. ${ }^{51}$

Sementara karya lainnya adalah kajian yang dilakukan oleh Von der Mehden tentang interaksi dan hubungan antara Islam di Asia Tenggara dan Islam di Timur Tengah. Karya ini berusaha mengungkapkan dinamika interaksi di antara kedua wilayah Muslim ini dalam berbagai aspek kehidupan, seperti politik, ekonomi, dan intelektual. ${ }^{52}$ Meski cukup berhasil dalam mengungkapkan dampak interaksi dan hubungan di antara wilayah ini dalam perkembangan

${ }^{49}$ Azra, Historiografi......., h. 7.

${ }^{50}$ Azra, Jaringan Ulama ...,

${ }^{51}$ Mona Abaza, Islamic Edication, Perception and Axchanges: Indonesia Students in Cairo, (Paris: Caheir d'Archipel No.33, 1993). Lihat juga Azra, Historiografi..., h. 4.

${ }^{52}$ Fred R. Von der Mehden, Two Worlds of Islam: Introduction Between Southeast Asia and Middle East, (Gainsville: University Press of Florida, 1993). 
Islam di Asia Tenggara, namun menurut Azra dalam segi-segi tertentu kajian ini memiliki kelemahan dan kekurangan yang cukup mencolok. ${ }^{53}$

Dengan demikian, historiografi Islam di Indonesia mengalami perkembangan bersamaan dengan perkembangan historiografi Indonesia itu sendiri. Penulisan sejarah Islam di Indonesia pada mulanya tidak memperlihatkan ciri yang jelas sebagai sejarah Islam, namun hanya berbentuk karya sastra klasik yang isinya banyak menyebutkan istilah-istilah kepada narasi tertentu seperti haba, hikayat, kisah, tambo dan lainnya yang berasal dari bahasa Arab.

Sementara corak historiografi awal Islam di Indonesia adalah historiografi yang mendekati sejarah Islam di Indonesia sebagai bagian dari sejarah umat Islam. Dalam hal ini, penekanan historiografi lebih ditekankan kepada periode dan memberikan penekanan kepada peranan pahlawan dan sultan dalam bangun dan tenggelamnya kerajaan Islam di Kepulauan Nusantara

Pada perkembangan selanjutnya, muncul pendekatan sejarah Islam sebagai bagian dari sejarah nasional Indonesia. Jadi, historiografi Islam di Indonesia pada masa ini dianggap sebagai bagian dari sejarah nasional Indonesia yang penekanannya pada sejarah sebagai proses dalam masyarakat yang terjadi karena pergeseran elemen-elemen yang terdapat dalam masyarakat itu.

Kemudian sejak 1960-an muncul penulisan sejarah Islam Indonesia yang sering disebut kalangan sejarawan Indonesia sebagai "sejarah baru" (new history) yang cenderung dipahami sebagai "sejarah sosial" (social history) yakni sejarah yang lebih menekankan kepada kajian dan analisis terhadap faktor-faktor bahkan ranahranah sosial yang mempengaruhi terjadinya peristiwa-peristiwa sejarah itu sendiri.

Dalam sejarah baru ini, historiografi Islam Indonesia tidak lagi dilihat dari perspektif lokal, tetapi dalam perspektif global dan total, yang melihat sejarah Islam di Indonesia dalam kaitan dengan perkembangan historis Islam di kawasan-kawasan lain.

${ }^{53}$ Azra, Historiografi..., h. 4. 


\section{Historiografi Sejarawan Informal}

Seperti halnya yang telah dijelaskan di atas, bahwa historiografi Islam di Indonesia pada mulanya tidak menampakkan ciri yang jelas sebagai sejarah Islam, namun hanya berbentuk karya sastra klasik yang isinya banyak menyebutkan istilah-istilah kepada narasi tertentu seperti haba, hikayat, kisah, tambo dan lainnya yang berasal dari bahasa Arab. Namun kemudian sejarah Indonesia dibangun atas dua pendekatan yakni sejarah Islam Indonesia sebagai bagian dari sejarah umat Islam dan sejarah Islam Indonesia sebagai bagian dari sejarah nasional Indonesia. ${ }^{54}$

Sementara corak historiografi awal Islam di Indonesia adalah historiografi yang mendekati sejarah Islam di Indonesia sebagai bagian dari sejarah umat Islam. Dalam hal ini penekanan historiografi lebih ditekankan kepada periode dan memberikan penekanan kepada peranan pahlawan dan sultan dalam bangun dan tenggelamnya kerajaan Islam di Kepulauan Nusantara.

Munculnya bermacam-macam bentuk sejarah Islam Indonesia, tentunya berbanding lurus dengan profesi penulis sejarah itu sendiri. Kuntowijiyo melihat bahwa sejarawan itu ada tiga golongan menurut pendidikannya (1) sejarawan profesional, (2) sejarawan dari disiplin lain, (3) sejarawan dari masyarakat.55 Sementara Azra memetakan sejarawan menjadi dua yaitu sejarawan prefesional (historian by profession) atau sejarawan akademik (academic historian) dan sejarawan informal (informal historian). ${ }^{56}$

Menurut Kuntowijoyo sejarawan profesional adalah sejarawan yang berasal dari lulusan lembaga pendidikan sejarah. Ia dibekali dengan bekal metodologi dan teori-teori ilmiah bidang ilmu sejarah. ${ }^{57}$ Sejarawan dari disiplin lain adalah sejarawan yang bukan lulusan pendidikan sejarah. Ia dapat berasal dari lulusan bidang hukum, eksakta, atau agama, namun meminati bidang sejarah, dan sejarawan dari masyarakat adalah sejarawan amatir”, ia tidak bergelar sarjana tapi belum tentu buruk menulis sejarah. ${ }^{58}$

\footnotetext{
${ }^{54}$ Umar, Historiografi Islam..., h. 188.

${ }^{55}$ Kuntowijoyo, Pengantar Пlmu Sejarah.., h. 83-85.

${ }^{56}$ Azra, Historiografi......, h. 83.

${ }^{57}$ Kuntowijoyo, Pengantar ..., , h. 84.

${ }^{58}$ Ibid., h. 85-86.
} 
Berbeda dengan Kuntowijoyo, Azra mengutip pendapat Carl Becker dengan memberi persamaan antara sejarawan akademik (academic historian) dengan "sejarah tinggi" dan sejarawan informal (informal historian) dengan "sejarah rendah". ${ }^{59}$ Menurut Azra sejarah tinggi adalah sejarah yang menghendaki berbagai kemampuan sejarawan dan peneliti sejarah untuk mengungkapkan dan menjelaskannya kepada publik. Sementara pengertian "sejarah rendah" memberikan pengertian sejarah secara sangat atau paling longgar. ${ }^{60}$

Dalam pandangan Azra selanjutnya, bahwa yang dikatakan sebagai sejarawan akademik atau sejarawan prefesional (historian by profession) adalah orang yang mampu membaca perkembanganperkembangan dalam ilmu sejarah yang tidak hanya menguasai teori dan metode sejarah saja, tetapi juga bidang-bidang keilmuan lain. Sejarawan dan peneliti sejarah tidak cukup lega hanya menghabiskan waktu meneliti arsip, dokumen, dan sumber-sumber sejarah lain, mereka harus pula menggulati sumber-sumber lain di luar bidang sejarah. ${ }^{61}$

Dengan demikian sejarawan akademis kelihatan menjadi semakin sulit karena dalam melakukan penelitian sejarah harus melintasi batas-batas sempit yang membatasi paradigma keilmuan sejarah untuk kemudian juga mengetahui ilmu-ilmu seperti antropologi, sosiologi, ilmu politik, psikologi, dan lain-lain. Karena itulah sejarah sekarang menjadi semakin antropologis (anthropological history), atau lebih sosiologis (sociological history), atau lebih psikologis (psychological history), dan seterusnya. Jika tidak, sejarawan atau peneliti sejarah akan gagal menjelaskan sejarah dengan cara yang menyakinkan dan mampu memberikan pencerahan kepada masyarakat. ${ }^{62}$ Sebaliknya, ilmu-ilmu lain juga semakin historis. Sebab itulah berkembang misalnya, antropologi historis (historical antropology), sosiologi historis (historical sociology).

Sementara sejarawan informal (informal historian) atau sejarah rendah Azra mengutip pendapat Becker yang memberikan

\footnotetext{
${ }^{59}$ Azra, Historiografi..., h. 83.

${ }^{60} \mathrm{Ibid}, \mathrm{h} .85$.

${ }^{61} \mathrm{Ibid}$, h. 83.

${ }^{62}$ Ibid , h. 83.
} 
pengertian sejarah secara sangat atau paling longgar. Becker mengatakan "history is the memory of things said and done". Dalam pengertian ini bahkan "sejarah sebagai kenangan tentang hal-hal yang dikatakan dan diperbuat (seseorang) tidak lagi menggunakan keterangan waktu "di masa silam". Karena jika definisi sejarah sebagai "kenangan tentang hal-hal yang dikatakan dan dilakukan" ditambahi dengan "di masa silam", maka tidak bisa dielakkan konotasinya adalah "masa silam yang jauh" (distant past). ${ }^{63}$

Sementara dalam pandangan Ibrahim Alfian sejarah itu dapat ditulis oleh siapa saja tanpa harus melalui jenjang akademik ilmu sejarah. Menurutnya, rekonstruksi masa lampau tidak hanya dilakukan oleh para sejarawan akademik yang mendapat pendidikan formal dalam ilmu sejarah dengan hasil yang idealnya deskriptif analitik, tetapi juga oleh para sejarawan amatir pada umumnya.

Pendapat Ibrahim Alfian ini juga didukung oleh Kuntowijoyo yang mengatakan, banyak penulis sejarah yang kita kira "amatir" ternyata menghasilkan karya karya bermutu. Kuntowijoyo memberi contoh bahwa Rusli Amran telah menulis sekitar Plakat Panjang di Sumatera Barat dengan penelitian yang lebih dari seseorang terdidik. Demikian juga Luckman Sinar yang sehari-harinya adalah pengusaha yang sibuk, masih sempat menulis sejarah dengan baik. ${ }^{64}$

Di Indonesia sendiri sejarawan informal sangat berperan dalam perkembangan sejarah penulisan Sejarah Islam Indonesia. ${ }^{65}$ Banyak dari mereka yang menghasilkan karya kesejarahan dan telah memberikan banyak kontribusi kepada aspek-aspek tertentu pengetahuan kita tentang sejarah manusia dan bangsa kita. Tidak ragu lagi telah membantu kita memahami sejarah kita secara lebih baik. ${ }^{66}$

Ada beberapa nama sejarawan informal yang telah menghasilkan karya sejarah monumental misalnya saja Hamka. Ia adalah seorang otodidak dalam berbagai bidang ilmu pengetahuan seperti filsafat, sastra, sejarah, sosiologi dan politik, baik Islam

${ }^{63}$ Ibid, h. 85.

${ }^{64}$ Kuntowijoyo, Metodologi Sejarah, Edisi Kedua, (Yogyakarta: Tiara Wacana, 2003), h. 86.

${ }^{65}$ Azra, Historiografi ....., h. $83-84$.

${ }^{66} \mathrm{Ibid}$, h. 83-84. 
maupun Barat. Ia juga termasuk seorang ulama, aktivis politik dan penulis yang produktif diantaranya adalah tentang sejarah umat Islam.

Selain Hamka, A. Hasymi asal Aceh juga merupakan sejarawan informal yang karya-karya sejarahnya juga telah memberikan banyak kontribusi kepada aspek-aspek tertentu pengetahuan kita tentang sejarah manusia dan bangsa kita. Tidak ragu lagi telah membantu kita memahami sejarah kita secara lebih baik.

Menurut Rosenthal, bentuk dasar historiografi Islam di Indonesia adalah karya sastra klasikyang isinya banyak menyebutkan istilah-istilah kepada narasi tertentu seperti haba, hikayat, kisah, tambo dan lainnya yang berasal dari bahasa Arab. ${ }^{67}$ Argumen ini didukung Hamka dalam melakukan penulisan Sejarah Umat Islam IV banyak bahannya yang diambil dari historiografi lokal meski bercampur mitos dan legenda, seperti Hikayat Raja-raja Pasai, Sejarah Melayu, dan lain-lain yang menjelaskan interaksi langsung antara Nusantara dengan Arabia. ${ }^{68}$ Adanya karangan klasik seperti haba, hikayat, kisah, tambo inilah yang oleh Resenthal disebut dapat dijadikan bahan penting dalam studi karya historiografi Islam, sehingga akan terbentuk suatu horizon baru di dalam penulisan sejarah Islam yang lebih banyak berpijak pada bumi sendiri dalam pengembangan keahlian dan pengetahuan sejarah Islam yang dilakukan oleh penulis-penulis Islam sendiri. ${ }^{69}$

Sementara Mukti Ali mengatakan, paling tidak terdapat dua corak pendekatan dalam penulisan sejarah Islam di Indonesia. Pertama, Pendekatan sejarah Islam Indonesia sebagai bagian dari sejarah umat Islam. Pendekatan historiografi ini lebih ditekankan kepada periode dan memberikan penekanan kepada peranan pahlawan dan sultan dalam bangun dan tenggelamnya kerajaan Islam di Kepulauan Nusantara, kedua, pendekatan sejarah Islam Indonesia sebagai bagian dari sejarah nasional Indonesia ${ }^{70}$ historiografi Islam di Indonesia pada masa ini dianggap sebagai bagian dari sejarah

\footnotetext{
${ }^{67}$ Umar, Historiografi ..., h. 188.

${ }^{68}$ HAMKA, Sejarah Umat Islam IV...

${ }^{69}$ Franz Rosenthal, A History of Muslim, (Leiden:E.J Brill, 1968), h. 8.

${ }^{70}$ Umar, Historiografi..., h. 188.
} 
nasional Indonesia yang penekanannya pada sejarah sebagai proses dalam masyarakat yang terjadi karena pergeseran elemen-elemen yang terdapat dalam masyarakat itu.

Kalau kita lihat karya Hamka "Sejarah Umat Islam IV" dalam historiografinya, ia menggunakan pendekatan sejarah Islam Indonesia sebagai bagian dari sejarah umat Islam. ${ }^{71}$ Karena dalam buku ini pengelompokannya lebih banyak ditekankan kepada periode daripada kepada daerah. Penekannya lebih banyak kepada peranan pahlawan dan sultan dalam bangun tenggelamnya kerajaan Islam di kepulauan nusantara, sehingga dengan demikian heroworship nampaknya dipegang oleh HAMKA dalam penulisan sejarah Islam.

Begitu juga A. Hasjmi, dalam bukunya "Sejarah Masuk dan Berkembangnya Islam di Indonesia" menggunakan pendekatan sejarah Islam Indonesia sebagai bagian dari sejarah umat Islam. Dalam bukunya tersebut ia lebih menekankan kepada periode dari pada daerah. Begitu juga peranan pahlawan dan sultan sangat dominan dalam bangun dan tenggelamnya kerajaan Islam di kepulauan nusantara. $^{72}$

Pendekatan semacam inilah, Hamka, kemudian melakukan revisi tentang sejarah pertama kali masuknya Islam ke Indonesia, yang kemudian dikenal dengan teori Arabia. ${ }^{73}$ Menurut Hamka, Islam masuk ke Indonesia datang langsung dari Makkah atau Madinah. Waktu kedatangannya pun bukan pada abad ke-12 atau 13, melainkan pada awal abad ke-7. Artinya, Islam masuk ke Indonesia pada awal abad hijriah, bahkan pada masa Khulafaur Rasyidin memerintah. Islam sudah mulai ekspidesinya ke Nusantara ketika sahabat Abu Bakar, Umar bin Khațab, Usman bin Affan dan Ali bin Abi Talib memegang kendali sebagai Amirul Mukminin. ${ }^{74}$

Hamka menolak pandangan yang menyatakan bahwa agama Islam masuk ke Indonesia pada abad ke 13 dan berasal dari Gujarat. Hamka lebih mendasarkan teorinya pada peranan bangsa Arab dalam penyebaran Islam di Indonesia. Gujarat hanyalah

${ }^{71}$ Ibid, ..., h. 188 .

${ }^{72}$ A. Hasjmi (ed), Sejarah Masuk dan Berkembangnya Islam di Indonesia, (Jakarta: Bulan Bintang, 1981), h. 375.

${ }^{73}$ HAMKA, Sejarah ..., h. 36-42.

${ }^{74}$ Hamka, Sejarah Umat Islam..., h. 6. 
merupakan tempat singgah, dan Mekah adalah pusat Islam, sedang Mesir sebagai tempat pengambilan ajaran. Hamka menekankan pengamatannya kepada masalah mazhab Syafi'i yang istimewa di Mekah dan mempunyai pengaruh besar di Indonesia.

Senada dengan Hamka, A. Hasjmi juga mempunyai pandangan yang sama kedatangan Islam di Indonesia bukan pada abad ke-12 atau ketiga belas, melainkan abad ke-7. Hal ini didasarkan pada naskah Idhār al-Ḥaqq fi Mamlakāt Ferlah wal Fasi, karangan Abu Ishak al-Makarani al-Fasi, Tazkirat Țabāqāt Jumū' Sultānul Salatin karya Syaikh Syamsul Bahri Abdullah, al-Asyi, dan Silsilah Raja-raja Perlak dan Pasai, A. Hasymi menyatakan bahwa Kerajaan Perlak, Aceh adalah kerajaan Islam pertama di Nusantara yang didirikan pada tanggal 1 Muharam 225 H (840 M) dengan raja pertamanya Sultan Alaudin Sayyid Maulana Abdil Aziz Syah. Teori ini kemudian banyak didukung oleh cendekiawan Nusantara dan dimasukkan dalam buku teks pengajaran Perguruan Tinggi. ${ }^{75}$

Teori Arabia ini diperkuat dengan bukti catatan-catatan resmi dan Jurnal Cina pada periode ini Dinasti Tang76 618 M yang secara ekplisit menegaskan bahwa Islam sudah masuk wilayah Timur jauh, yakni Cina dan sekitarnya ${ }^{77}$ pada abad pertama Hijriah melalui lintas laut dari bagian Barat Islam. Cina yang dimaksudkan pada abad pertama Hijriah tiada lain adalah gugusan pulau-pulau di Timur Jauh termasuk Kepulauan Indonesia. ${ }^{78}$ Jurnal Cina juga mengisyaratkan adanya pemukiman Arab di Cina yang penduduknya diizinkan oleh Kaisar untuk sepenuhnya menikmati kebebasan beragama. ${ }^{79}$ Pada masa itu orang-orang Islam memilih pemimpin mereka sendiri yang dinamakan imam, ${ }^{80}$ dan sejak masa itu perdagangan Indonesia mulai lancar dan maju.

\footnotetext{
${ }^{75}$ A. Hasjmi (ed), Sejarah Masuk..., h. 375.

${ }^{76}$ Sartono Kartodirjo, Sejarah Nasional Indonesia, vol. II, (Jakarta: Depdikbud, 1977), h. 73.

${ }^{77}$ G. R. Tibbets, "Early Muslim Trade in South Asia" Vol. 30 (t.t.: MBRAS, 1957 ), h. 39 .

${ }^{78}$ Yaqut Al-Hamari, Mu'jam Al-Buldan, vol. III (Beirut: Dar Shadir, 1971), h. 440. 1995), h. 440.

${ }^{79}$ Dr. J.C. van Leur, Indonesian Trade and Society, (Den Haag, W. Van Hoeve Ltd,

${ }^{80}$ Alnold, T. W. The Preaching of Islam, (London:t.p, 1935), h. 331-332.
} 
Selain itu, laporan Cina yang menegaskan keputusan bangsa Arab mengirim utusan kepada Kerajaan Ho Long. Kerajaan Arab mengirim utusan ke Kerajaan Ho Long sekitar tahun 640 M, 666 M, dan 674 M. ${ }^{81}$ Sementara Kerajaan Ho Long sendiri menurut Alwi Sihab $^{82}$ terletak di Jawa Timur yang bernama Kerajaan Kalingga yang terkenal dengan kemajuan dan kesejahteraan rakyat serta keadilan pemerintahannya. Sementara yang mengutus oleh orang-orang Cina dikenal dengan sebutan "Tasheh" sebagai nama yang mereka kenal untuk kerajaan Arab. ${ }^{83}$ Jadi, pengenalan dini kaum Muslimin (Arab) terhadap Kepulauan Indonesia setaraf dengan data yang mereka ketahui mengenai Cina bahkan lebih luas. Jika demikian halnya, alasan apakah gerangan yang menjadi penghalang untuk menetapkan bahwa Islam masuk ke Indonesia pada abad pertama Hijriah. Yaitu, pada masa pedagang-pedagang Muslim memasuki Cina kerena kedatangan orang-orang Arab membawa Islam ke Cina melalui jalur laut lama.

Dari data-data sejarah yang ada, maka jelaslah bahwa bobot historiografinya Hamka dapat dipertanggung jawabkan secara akademis. Karena ia telah menggunakan metodologi sejarah dengan benar. Dalam penulisan buku sejarah Umat Islam ini, Hamka telah melakukan kritik ekstern untuk menilai tentang ke-autentik-an dokumen sejarah dengan melakukan perjalanan ke tempat yang dijadikan obyek penulis sejarahnya ${ }^{84}$ Disamping itu, Hamka juga melakukan kritik intern terhadap sumber-sumber tersebut untuk menyakinkan bahwa dokumen itu autentik.

Sementara sumber sejarah yang ia gunakan berasal dari tiga sumber yaitu dengan mengambil dari historiografi lokal seperti Hikayat Raja-raja Pasai, Sejarah Melayu dengan membuang hal-hal yang bercampur mitos dan legenda, hasil penelitian orang Belanda dan orang Inggris serta pengembaraan Hamka keliling Indonesia sehingga menghasilkan sumber asli dari sejarah itu sendiri. ${ }^{85}$

${ }^{81}$ Grenvelt, W.P., Historical Notes on Indonesia and Malaya Compiled From Chinese Sources, (1960), h. 201.

${ }^{82}$ Sihab, Antara Tasawuf ..., h. 11.

${ }^{83}$ Kartodirjo, Sejarah ..., h. 73.

${ }^{84}$ Hamka, Sejarah Umat Islam..., h. 5.

${ }^{85}$ Ibid..., h. 7. 
Sementara historiografi A. Hasjmi tidak setinggi historiografinya Hamka. Hal ini terjadi karena sumber sejarah yang dipergunakan oleh A. Hasjmi hanya terbatas pada buku-buku sejarah yang telah ditulis oleh sejarawan sebelumnya. Di samping itu, ia tidak melakukan kritik terhadap sumber sejarah itu. Hal ini terbukti ketika ia berpendapat bahwa kerajaan Islam pertama di Indonesia terletak di Perlak, ia tidak melakukan penelitian akan tetapi hanya bersumber dari naskah Idhār al-Haqq fi Mamlakat Ferlah wal Fasi, karangan Abu Ishak Al-Makarani Al-Fasi, Tazkirat Tabāqāt Jumū' Sultānul Salatin karya Syaikh Syamsul Bahri Abdullah, AlAsyi, dan Silsilah Raja-raja Perlak dan Pasai. ${ }^{86}$ Sejarawan informal berikutnya yang patut dipertimbangakan dengan karya-karya sejarahnya yang produktif dan kontroversial adalah Joesoef Sou'yb. Seorang sejarawan informal yang berasal dari Sumatera Barat yang berkarir di Sumatera Utara tepatnya di Kota Medan. Ia tidak hanya menulis buku-buku sejarah melainkan buku-buku dalam berbagai disiplin ilmu seperti bahasa, sastra, logika, ilmu kalam, filsafat, hingga komunikasi dan jurnalistik. Namun yang menjadi fokus perhatian dalam tulisan ini adalah memotret kedudukannya sebagai sejarawan informal dan melihat corak historiogafinya.

Jika dibandingkan kedua sejarawan informal tersebut diatas dengan Joesoef Sou'yb, maka terdapat beberapa persamaan dan perbedaan dalam histogriorafinya. Adapun persamaan dari historiografi dari ketiga sejarawan informal tersebut menyangkut tentang pertama masuknya Islam di Indonesia. Dalam bukunya "Pelaut Indonesia menemukan Benua Amerika Sebelum CH. Columbus" Sou'yb sependapat dengan teori Arabia, karena menurutnya, bahwa armada dagang pihak Islam (Arab-Parsi) sejak abad ke-7 Masehi saling berhubungan dengan armada imperium Sriwijaya sampai abad ke$14 \mathrm{M}$. Pedagang Islam ini kemudian mendirikan perkampungan di pesisir Sumatera barat sejak tahun $674 \mathrm{M}$. dari fakta itulah maka Islam masuk ke Indonesia lewat dakwah dan penyebaran lewat budaya seperti memperkenalkan bahasa arab sebagai percakapan sehari-hari pada pusat kedudukan imperium Sriwijaya. ${ }^{87}$

\footnotetext{
${ }^{86}$ A. Hasjmi (ed), Sejarah Masuk..., h. 372.

${ }^{87}$ Soūyb, Lihat Pelaut.., h. 47.
} 
Sementara perbedaannya adalah Sou'yb telah memperkenalkan penulisan sejarah Islam Indonesia yang bercorak global dan total. Perkembangan ini terlihat jelas dalam bukunya terutama dalam bukunya "Pelaut Indonesia menemukan Benua Amerika Sebelum CH. Columbus". Dalam bukunya ini Sou'yb tidak menekankan historiografi pada periode dan menekankan kepada "individu", namun telah memperkenalkan satu model general atau total history. Dalam kontek ini, Sou'yb menempatkan sejarah Islam Indonesia dan masyarakat Islam Indoensia dalam totalitas kehidupan manusia. ${ }^{88}$

Sejarah Islam, bagi Sou'yb, hanya bisa dipahami dalam kerangka lebih luas; totalitas tidak terbatas pada Islam, sejarah masyarakat-masyarakat muslim, dan produk peradaban yang berkarakter Islam, tetapi juga dalam konteks sejarah manusia dan peradabannya secara keseluruhan. ${ }^{89}$ Pendekatan Sou'yb ini tentu mempunyai peranan yang besar dalam perkembangan historiografi Islam Modern di Indonesia. Dimana pendekatan historiografi Islam modern di Indonesia telah mengarah kepada persepektif global, yang melihat sejarah Islam di Indonesia sepanjang sejarah tak bisa dilepaskan dari perkembangan Islam di Arabia dan kawasan-kawasan Muslim lainnya. ${ }^{90}$

Dari uraian tentang historiografi sejarawan informal di atas dapat diambil kesimpulan bahwa Joesoef Sou'yb sependapat dengan sumber sejarah kedua sejarawan diatas bahwa Islam masuk ke Indonesia datang langsung dari Makkah atau Madinah ditandai dengan adanya saling hubungan antar armada dagang pihak Islam (Arab-Parsi) sejak abad ke-7 Masehi dengan armada imperium Sriwijaya, ditandai dengan adanya perkampungan di pesisir Sumatera Barat sejak tahun 674 M. dari fakta itulah maka Islam masuk ke Indonesia lewat dakwah dan penyebaran lewat budaya.

Sementara dalam persoalan konsep dan model historiografi Sou'yb telah memperkenalkan penulisan sejarah Islam Indonesia yang bercorak global dan total. Sou'yb tidak menekankan historiografi

${ }^{88}$ Azra, Historiografi ......, h. 69.

${ }^{89}$ Pendekatan Soūyb ini juga mempunyai kemiripan dengan apa yang telah dilakukan oleh Hodgson dalam bukunya The venture of Islam: Conscience and History in a World Civilization, (Chicago: The University of Chicago, 1974).

${ }^{90}$ Azra, Jaringan Ulama..., h. 123. 
pada periode dan menekankan kepada "individu", namun telah memperkenalkan satu model general atau total history.

Sejarah Islam, bagi Sou'yb, hanya bisa dipahami dalam kerangka lebih luas; totalitas tidak terbatas pada Islam, sejarah masyarakat-masyarakat muslim, dan produk peradaban yang berkarakter Islam, tetapi juga dalam konteks sejarah manusia dan peradabannya secara keseluruhan.

Setelah menguraikan corak dan bentuk historiografi dua sejarawan informal yaitu, HAMKA dan Ali Hasyimi maka aspek yang dibandingkan mengacu pada tiga hal yaitu, (1) Dari corak historiografinya, (2) Dari bobot historiografinya (3) Dari produktivitas karya-karyanya. Antara HAMKA dan Ali Hasyimi dan Joesoef Sou'yb sama-sama memiliki corak modern-konvensional artinya karena memang kedua sejarawan yang dibandingkan adalah sama-sama hidup sezaman dan berasal dari sejarawan informal maka perbedaan antara keduanya tidak terlalu signifikan.

Dari aspek bobot historiografi yang dihasilkan HAMKA memiliki bobot yang lebih besar jika dilihat dari perspektif popularitasnya. Hal ini dapat dipahami karena HAMKA adalah tokoh nasional yang hidup di Jakarta ibu kota negara. Selain itu HAMKA juga adalah salah seorang ketua MUI Pusat yang fatwa-fatwanya dan sikap konsistensinya dalam masalah keislaman sudah diakui oleh masyarakat Indonesia secara luas. HAMKA juga pernah memimpin salah satu Ormas Islam terbesar di Indonesia yaitu Muhammadiyah pada periode tertentu. Dengan pertimbangan-pertimbangan di atas maka dengan sendirinya karya-karya HAMKA termasuk karya sejarahnya memiliki bobot tersendiri dalam pandangan masyarakat dalam arti bahwa kualitas karya-karya sejarahnya sudah tidak diragukan lagi. Dari aspek produktivitasnya baik HAMKA maupun Ali Hasyimi dibandingkan dengan Joesoef Sou'yb maka jika melihat dari karya-karya yang dihasilkan serta dari aspek keragaman hasil karyanya maka Joesoef Sou'yb lebih menonjol dibandingkan dengan HAMKA dan Ali Hasyimi.

\section{E. Penutup}

Menilai suatu hasil karya khususnya karya sejarah seharusnya diletakkan dalam konstruk pemikiran yang benar dan adil. Jika 
tidak, akan terjadi kesalahpahaman yang berujung pada kesalahan sikap dalam memberikan penilaian terhadap karya-karya tertentu. Kesalahan paradigma juga berpotensi meniadakan nilai pada karya yang sebenarnya bernilai tinggi menjadi sebuah karya yang seolaholah tidak bernilai sama sekali.

Hal ini terjadi di kalangan sejarawan informal jika karyakarya mereka disejajarkan dengan karya-karya sejarawan akademik. Seakan-akan nilai historiografi yang standar hanya dimiliki oleh sejarawan akademik, sementara sejarawan informal tidak memiliki tempat di dalam khazanah historiografi yang ada. Padahal dari aspek produktifitas para sejarawan informal itu cenderung lebih produktif dalam melahirkan karya-karya sejarah sepanjang zaman. Agar masalah ini tidak berkelanjutan dalam persepsi yang keliru maka Kuntowidjoyo telah membagi tiga kategori sejarawan yaitu Sejarawan Profesional, sejarawan dari disiplin ilmu lain, dan sejarawan dari masyarakat. Begitu pula Azyumardi Azra memetakan sejarawan ke dalam dua kategori utama yaitu, sejarawan akademik dan sejarawan informal yang memiliki makna tersendiri.

Artinya para sejarawan yang masuk dalam kategori informal seperti yang ditulis dalam artikel ini merupakan sejarawan yang dapat diterima keberadaannya sesuai dan fungsi dan kedudukan mereka sebagai sejarawan informal yaitu sejarawan yang bukan berasal dari lembaga pendidikan sejarah dan tidak pula mendapatkan pembekalan secara mendalam tentang metodologi dan teori-teori ilmiah di bidang sejarah, namun menaruh perhatian yang besar tentang isu-isu sejarah, dan menuliskannya dalam bentuk buku-buku sejarah seperti Prof. Dr. Hamka, A. Hasyimi, dan Joesoef Sou'yb. []

\section{Daftar Pustaka}

Abdullah, Taufik, (ed). Agama dan Perubahan Sosial. Diterbitkan untuk Yayasan Ilmu-Ilmu Sosial, Jakarta: Rajawali, 1983.

, (ed). Sejarah dan Masyarakat: Lintasan Historis Islam di Indonesia. Jakarta: Pustaka Firdaus.1985.

, (ed.), Sejarah Lokal di Indonesia, Yogyakarta: UGM Pres, 1990. 
dan Abdurrachman Surjomihardjo. Ilmu Sejarah dan Historiografi: Arah dan Perspektif. Jakarta: PT Gramedia, 1985. dan M.Rusli Karim, (Eds.). Metodologi Penelitian Agama Sebuah Pengantar. Yogyakarta: Tiara Wacana, 1991.

dan Moh. Hisyam, (ed.). Sejarah Umat Islam Indonesia, Edisi Revisi. Jakarta: MUI Pusat bekerjasama dengan Yayasan Pustaka Umat, 2003.

dan Sharon Siddique, (ed), Tradisi dan Kebangkitan Islam di Asia Tenggara. Terj. Rochman Achwan, Jakarta: LP3ES, 1989. , (ed), Sejarah Lokal di Indonesia. Yogyakarta: UGM University Press, 1990.

, dan Abdul Rahman Haji. Pengantar Ilmu Sejarah. Kuala Lumpur: Penerbit Bersama, 1994.

, Dkk., Manusia dalam Kemelut Sejarah. Jakarta: LP3ES, 1983.

, Islam dan Masyarakat Pantulan Sejarah Indonesia, Jakarta: LP3ES, 1987. , Islam di Indonesia, Jakarta: Tintamas, 19974.

Abdullah, Yusri Abdul Ghani, Historiografi Islam Dari Klasik Sampai Moderen, terj.Budi Sudrajat. Jakarta: Raja Grafindo Persada, 2004.

Alwi, Haddad bin Thahir, Sejarah Masuknya Islam di Timur Jauh, terj. S. Dhiya Shahab. Jakarta: Lentera Basritama, 1995.

Arnold, T.W., The Preaching of Islam : History of Propagation of the Muslim Faith. Delhi : Low Price Publications. 1995.

Azra, Azyumardi, (ed) "Hadhrāmi Scholars in the Malay-Indonesia Diaspora: A Preliminary Study of Sayyid 'Uthmān', Studia Islamika, IAIN Jakarta. 1995.

, (ed). Islam Nusantara: Jaringan Global dan Lokal, Bandung: Mizan, 2002.

dan Idris Thaha (ed). Historiografi Islam Kontemporer:

Wacana Aktualitas dan Aktor Sejarah. Jakarta: PT. Gramedia Pustaka Utama, 2002. 
, Menjadi Indonesia: 13 Abad Eksistensi Islam di Bumi Nusantara, Komaruddin Hidayat dan Ahmad Gaus AF (ed). (Bandung: Mizan, 2006).

, Peranan Hadits Dalam Perkembangan Historiografi Awal Islam, Orasi Ilmiah pada Dies Natalis ke 36 IAIN Syarif Hidayatullah Jakarta, 1993.

Burke, Peter, Sejarah dan Teori Sosial. Pengantar Dr. Mestika Zed, Jakarta: Yayasan Obor Indonesia, 2003.

FR., Ankersmit, Refleksi Tentang Sejarah: Pendapat-pendapat Modern tentang Filsafat Sejarah, terj. Dick Hartoko. Jakarta: PT. Gramedia, 1984.

Frederick, H. William dan Surenoto, Soeri, Pemahaman Sejarah Indonesia. Jakarta: LP3ES, 1982.

Gardiner, Juliet, What Is History Today? London: Macmilan Education, LTD. 1985.

Gazalba, Sidi, Pengantar Sejarah Sebagai Ilmu. Jakarta: Bhratara Karya Aksara, 1981.

Koentjaraningrat. et al. Metode-metode Penelitian Masyarakat. Jakarta: Gramedia. 1981.

Kuntowijoyo, Metodologi Sejarah, Edisi Kedua. Yogyakarta: Tiara Wacana, 2003.

Mahasin, Aswab, et.al. (eds.), Ruh Islam Dalam Budaya Bangsa: Agama dan Masalah Masa Kini Forum Festival Istiqlal II 1995. Jakarta: Yayasan Festival Istiqlal, 1996.

, Kajian Naskah-naskah Klasik dan Penerapannya bagi Kajian Sejarah Islam di Indonesia. Jakarta: Puslitbang Lektur Keagamaan Badan Litbang dan Diklat Departemen Agama, 2006.

, Modern Javanese Historical Tradition. London, 1978.

, The Arriival and Expantion of Islam in Indonesia Relating to South East Asia, Masagung Foundation, 1985.

Majalah Dialog, No.14, Ministry of Religious Affairs RI, Jakarta, 1983. 
Mastuhu dan Ridwan, M. Deden, (ed.), Tradisi Baru Penelitian Agama Islam Tinjauan Antar Disiplin Ilmu. Bandung: Kerjasama PUSJARLIT dan Nuansa, 1998.

Ricklefs, M.C., Sejarah Indonesia Moderen. Yogyakarta: UGM Pres, 1991.

Umar, Muin, Historiografi Islam, Jakarta: Rajawali Press, 1988.

Kartodirjo, Sartono, Lembaran Sejarah, No.1 Juni 1974. , Pemberontakan Petani Banten 1888. Pustaka Jaya : Jakarta. , Pemikiran dan Perkembangan Historiografi Indonesia: Suatu Alternatif. Jakarta: PT. Gramedia Jakarta, 1982.

, Pendekatan Ilmu Sosial Dalam Metodologi Sejarah. Jakarta: Gramedia, 1992. , Pengantar Sejarah Indonesia Baru 1500-1900: dari Emporeum Sampai Imperium. Jakarta: Gramedia, 1992.

Shills (ed) \& L., David, International Encyclopaedia of Social Sciences. Vol. V. New York: The Macmillan Company \& The Free Press. 1972.

Soedjatmoko, Dkk, (ed.) Historiografi Indonesia: Sebuah Pengantar. Jakarta: PT. Gramedia Pustaka Utama, 1995.

Yatim, Badri, Sejarah Sosial Keagamaan Tanah Suci Hijaz (Mekah dan Madinah) 1800-1925. Jakarta: Logos Wacana Ilmu, 1999. 
M.Yakub

halaman ini bukan sengaja dikosongkan 